\title{
Overview of Photovoltaic Thermal (PVT) Water Collector
}

\author{
Ahmad Fudholi ${ }^{1}$, Nur Farhana Mohd Razali ${ }^{2}$, Abrar Ridwan ${ }^{3}$, Rado Yendra ${ }^{4}$, Hartono ${ }^{5}$, Ari Pani \\ Desvina $^{6}$, Majid Khan Bin Majahar Ali $^{7}$, Kamaruzzaman Sopian ${ }^{8}$ \\ ${ }^{1,2,8}$ Solar Energy Research Institute, Universiti Kebangsaan Malaysia, Bangi Selangor, Malaysia \\ ${ }^{3}$ Prodi Teknik Mesin, Fakultas Teknik, Universitas Muhammadiyah Riau, Indonesia \\ ${ }^{4,5,6}$ Department of Mathematics, Faculty of Science and Technology, Universitas Islam Negeri Sultan Syarif Kasim (UIN \\ Suska), Pekanbaru, Riau, Indonesia \\ ${ }^{7}$ School of Mathematical Sciences Universiti Sains Malaysia, Gelugor, Malaysia
}

\begin{tabular}{l}
\hline Article Info \\
\hline Article history: \\
Received Jan 30, 2018 \\
Revised Jun 6, 2018 \\
Accepted Jun 20, 2018 \\
\hline
\end{tabular}

\section{Keyword:}

Electrical

PVT

Renewable

Solar

Thermal

\begin{abstract}
The popular solar technology is the integration of solar thermal technology and photovoltaic (PV), called photovoltaic thermal (PVT) technology. This technology converts solar energy to electrical and thermal energy. The efficiency of solar energy conversion via PVT is higher than photovoltaic and solar systems. PV cell efficiency decreases if system operating temperature is higher. Therefore, solar systems attached to PV cells act to cool PV cells and increase the overall efficiency of the PVT system. PVT construction that saves space, is suitable for domestic consumption, and long-term saving costs makes PVT current research by researchers in the latest energy technology. This review presents descriptions and previous works conducted on performances analysis of PVT water collector. Results on the performances of PVT water collectors are summarized. The energy and exergy efficiency of PVT water collector ranges from $28.5 \%$ to $85 \%$ and $6.8 \%$ to $14 \%$, respectively.
\end{abstract}

Copyright $(2018$ Institute of Advanced Engineering and Science. All rights reserved.

\section{Corresponding Author:}

Ahmad Fudholi,

Solar Energy Research Institute, Universiti Kebangsaan Malaysia,

43600 Bangi Selangor, Malaysia.

Email: a.fudholi@gmail.com

\section{INTRODUCTION}

Growth in the field of renewable energy and energy efficiency has brought stability to the negative impact of carbon emissions as a result of increasing world energy consumption as well as the reduction of major fossil fuel resources. Global awareness in the exploration of renewable energy signaled that renewable energy would be an option in the future. Renewable energy ensures adaptation to climate change, continuous energy supply, new job opportunities, environmental health and energy delivery to remote areas. At present, advances in the field of renewable energy bring impact to areas such as transport, cooling, heating and power generation in rural areas. Nevertheless, renewable energy savings in each year are far from the rate of achievement set. The reason for this is that subsidized payments to fossil fuels are still ongoing, low energy efficiency technologies and expensive installation costs. Solar energy is one of the renewable energy sources and this clean energy has potential to meet a significant amount of the world's energy demand. The evolution of renewable energy sources such as solar energy is a source of energy that provides benefits to the environment and clean energy [1]-[6].

Photovoltaic (PV) technology converts solar energy into electricity for use in various applications such as water and space heating purposes, electrical use for home appliances and solar drying. The efficiency of PV cell conversion from solar energy to electricity decreases as operating temperatures increase. Combining solar thermal collectors and PV cells in a system known as thermal photovoltaic (PVT) can reduce operating temperature and improve system efficiency. PVT also produces thermal energy and thermal 
energy simultaneously. A PVT collector consisting of PV panel, insulation and frame. Accordingly, PVT collector consists of one or more cover (glass sheets) or a transparent material placed above an absorbing plate with air flowing around it. One way to enhance the collector's efficiency of PVT collector is use heat transfer area through absorber with finned absorber, corrugated surfaces, and porous media [7]-[8]. PVT collectpr can be classified into four types base on heat transfer medium; air-based PVT collector, water-based PVT collector, the combination of water/air-based PVT collector, and nanofluid-based PVT collector [9].

Various studies have shown that increased energy efficiency and energy-saving photovoltaic hybrid systems compared to self-developed solar and photovoltaic collector systems [10] [11]. PVT studies include experimental studies, analytical and simulation solutions. The lower operating temperature and the increase in electrical efficiency of the PV module were recorded by Bahaidarah et al. [12] when the PV module was fitted with water cooling.

Recently, enviroeconomic and exergoeconomic analyses for PVT water collectors were studied base on thermodynamics aspect [13]. Thermodynamics is the study of heat, work, energy, and the changes they produce in the states of systems. In wider sense, thermodynamics examines the relationships between the macroscopic properties of a system. A system is in the state of thermodynamic equilibrium when no change in any microscopic properties takes place. In this review, thermodynamic aspect is focused involving exergy analysis. Exergy analysis is conducted by utilizing the first and second law of thermodynamics. Exergy analysis has become an essential tool in the system design, analysis, and optimization of thermal systems [14]-[15]. Fudholi et al. [16] studied theoretical and experimental of PVT air collector with $\nabla$-groove. They reported that PVT exergy efficiencies of were 12.66-12.91\% and PVT energy efficiencies were 31.2194.24\%. The thermal and PV efficiency was $21.3-82.9 \%$ and $9.87-11.34 \%$ respectively. Sarhaddi et al. [17] [18] studied energy and exergy analysis of PVT air collector. They reported that PV, thermal and PVT efficiency were $10 \%, 17.18$ and 45\% respectively. PVT exergy efficiency was $10.75 \%$. Recently, energy and exergy analysis for nanofluid based PVT systems were studied.Further theoretical approaches had been done such for the use of nanofluids as coolants as had been carried out by Mustafa et al. [19] which a theoretical model was performed to evaluate system's performance while studied numerically a new configuration of the photovoltaic thermal system which includes the collector tube and working fluid. Lari and Sahin [20] reported that PV energy efficiency was $13.2 \%$ for PVT nanofluid system. Aisyah et al. [21] studied PVT water collector with spiral thermal absorber design. They reported that the efficiency of PV, thermal and PVT were $4.18 \%, 76.68 \%$ and $80.86 \%$. However, in this review we focused on energy and exergy analysis of PVT water collector.

\section{DESIGN AND PERFORMANCE OF FLAT PLATE PVT WATER COLLECTORS}

Figure 1 shows PVT water collectors, has similar structure as the conventional flat plate solar collectors. The absorber consist of tube is attached to the PV panel in order to use for heating purposes. The PVT water collector could achieve the enhance cooling effectiveness compared to the air based system due to the high thermal mass of the of water over the air.
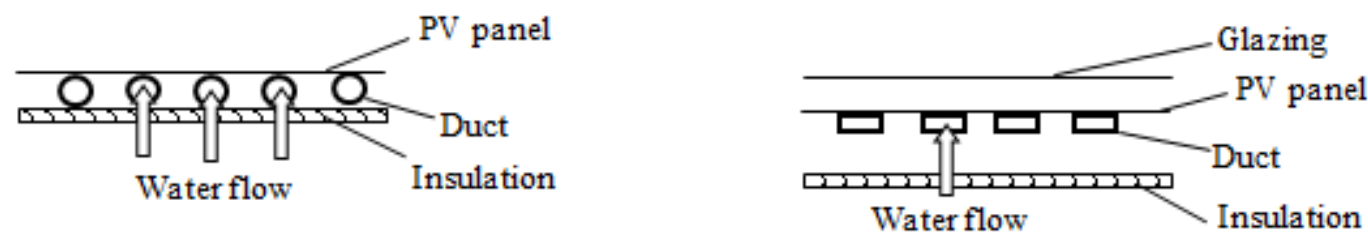

Figure 1. Flat plate PVT water collectors

The PVT technology is a technology developed to remove accumulated heat from the PV module and use the heat waste in an appropriate way. It combines PV cells and solar collector into a single module. This approach allows the cooling of PV cell and simultaneously utilizing the extracted heat for domestic use. Base on energy analysis, the overall efficiency of PVT, $\eta_{P V T}$ is the sum of solar collector thermal efficiency, $\eta_{t h}$ and PV's electrical efficiency, $\eta_{P V}$ used to evaluate the performance of PVT written as follows:

$$
\eta_{P V T}=\eta_{t h}+\eta_{P V}
$$


Electrical energy $\left(\eta_{f}\right)$ is a high-grade from of energy gain, the primary energy-saving efficiency was proposes as another performance indicator of the energy-grade difference between electricity and thermal energy andwas given by [18], [22]:

$$
\eta_{f}=\eta_{t h}+\frac{\eta_{P V}}{\eta_{p}}
$$

Where $\eta_{p}$ is the electric-power generation efficiency of a conventional power plant; its value can be taken as 0.38 . The evaluation indicator of the primary energy-saving efficiency also considers the quality and quantity of the energy that the PVT collector converts into solar energy [22].

The thermal efficiency of flat plate PVT collector is a ratio of the useful thermal energy, $Q_{u}$ to the overall incidence irradiations, $I$.

$$
\eta_{\mathrm{th}}=\frac{Q_{u}}{I}
$$

The heat collected by the flat plate PVT collector can be measured by result of average mass flow rate, $\dot{\mathrm{m}}$ heat capacity of flowing medium, $C_{p}$ and a temperature difference of the medium at the collector inlets, $t_{i}$ and outlets, $t_{o}$.

$$
Q_{u}=\dot{\mathrm{m}} C_{p}\left(t_{0}-t_{i}\right)
$$

The electrical efficiency of PV modules, $\eta_{p v}$ which is the ratio of measured output power to the overall incident solar radiation.

$$
\eta_{P V}=\frac{P_{o}}{I A_{c}}
$$

It is known that the electrical efficiency of the PV module is a function of temperature given by [22]

$$
\eta_{P V}=\eta_{r}\left(1-0.0045\left(T_{c}-25\right)\right)
$$

where $\eta_{r}$ is the reference efficiency of the PV module and $T_{r}$ is cell temperature.

Exergy analysis is a method that uses the conservation of the second law of thermodynamics for the analysis, design and improvement of energy (and other) systems. It is a useful method in achieving the goal of more efficient energy use as it enables us to determine the location, type and magnitude of wastes and losses. Exergy analysis can indicate whether or not and by how much a design of the energy system can be made efficient by reducing the inefficiencies in the system [23]-[27].

However, in order to evaluate the efficiency of the system more precisely, the exergy efficiency must be calculated using exergies for thermal and PV (electrical). Assuming that the effects due to the potential and kinetic energy changes are insignificant, the general exergy balance can be expressed as following [28]:

$$
\sum E x_{i}-\sum E x_{0}=\sum E x_{d} \text { or } \sum E x_{i}-\sum\left(E x_{\text {th }}+E x_{P V}\right)=\sum E x_{d}
$$

Where

$$
\begin{aligned}
& E x_{i}=A N I\left[1-\frac{4}{3}\left(\frac{T_{a}}{T_{s}}\right)+\frac{1}{3}\left(\frac{T_{a}}{T_{s}}\right)^{4}\right] \\
& E x_{P V}=\eta_{P V} A I
\end{aligned}
$$




$$
E x_{t h}=Q_{u}\left(1-\frac{T_{a}+273}{T_{o}+273}\right)
$$

where $T_{a}, T_{o}$ and $T_{s}$ are ambien, outlet and sky temperatures $\left(\mathrm{T}_{\mathrm{s}}=5777 \mathrm{~K}\right) . A, N$ and $I$ are area of PV, number of PV and irradiations, respectively.

The exergy efficiency of a PVT water collector is defined as ratio of net output exergy to net input exergy. It can be calculated as following:

$$
\eta_{E x_{i} P V T}=\frac{E x_{0}}{E x_{i}}=1-\frac{E x_{d}}{E x_{i}}
$$

The exergy loss of PVT water collector includes six term; (i) by optical losses in PVT collector surface, (ii) exergy destruction due to the temperature difference between the sun and PVT collector surface, (iii) exergy destruction due to heat transfer from the PVT surface to the working fluid at finite temperature difference, (iv) by heat loss from PVT collector to surrounding, (v) exergy destruction due to pressure drop in flow pipes and (vi) electrical exergy destruction [29].

\section{STUDIES CONDUCTED ON PVT WATER COLLECTORS AN OVERVIEW}

Zondag et al. [30] evaluated seven different designs of PVT water collector. The designs were categorised to sheet and tube, channel, free flow and two absorbers. Although the sheet and tube design is indicated $2 \%$ less in efficiency than the channel design, it is the easiest design for manufacturing process. Thus, this design is the most promising compared to other designs. Several studies on the performances (energy or exergy) analysis of PVT water collectors were reported as shown in Table 1.

\begin{tabular}{|c|c|c|c|c|c|c|}
\hline \multirow[b]{2}{*}{ Ref. } & \multirow[b]{2}{*}{ Year } & \multirow[b]{2}{*}{ Study } & \multicolumn{3}{|c|}{ Energy efficiency (\%) } & \multirow{2}{*}{$\begin{array}{c}\text { PVT } \\
\text { Exergy } \\
\text { efficiency }\end{array}$} \\
\hline & & & PV & Thermal & PVT & \\
\hline [31] & 2017 & Theoretical and experimental & 7.6 & 54 & NA & NA \\
\hline [32] & 2017 & Theoretical and experimental & 10 & 35 & NA & NA \\
\hline [33] & 2016 & Theoretical and experimental & 28 & 60 & NA & NA \\
\hline [34] & 2016 & Theoretical and experimental & NA & $40-50$ & $45-63$ & NA \\
\hline [35] & 2016 & Theoretical and experimental & NA & 75 & 69 & NA \\
\hline [36] & 2016 & Theoretical & 17 & 70 & NA & NA \\
\hline [37] & 2016 & Theoretical & 16 & NA & NA & NA \\
\hline [38] & 2016 & Theoretical and experimental & 13.19 & 62 & NA & NA \\
\hline [39] & 2016 & Experimental & NA & $51.5-52.8$ & NA & NA \\
\hline [40] & 2015 & Theoretical and experimental & $13.4-23.2$ & NA & $28.5-53.4$ & NA \\
\hline [41] & 2015 & Theoretical & $10.2-10.8$ & $44.6-49$ & NA & NA \\
\hline [42] & 2015 & Experimental & 12.9 & 68.2 & NA & NA \\
\hline [43] & 2015 & Theoretical & $7.5-8.7$ & $51.6-52$ & NA & $9.6-9.7$ \\
\hline [28] & 2014 & Experimental and theoretical & 11.4 & $45-51$ & $55-62$ & $12-14$ \\
\hline [44] & 2013 & Experimental & $10-10.4$ & $28.2-45.9$ & NA & NA \\
\hline [45] & 2013 & Experimental & $11.4-11.8$ & $39.4-40.7$ & NA & NA \\
\hline [46] & 2012 & Experimental & 14 & 29 & 43 & NA \\
\hline [47] & 2012 & Experimental & $14-15$ & $66-70$ & $70-85$ & NA \\
\hline [48] & 2012 & Experimental & 14.3 & 51 & 65.3 & NA \\
\hline [49] & 2012 & Experimental and theoretical & $1.5-4.3$ & $23-38$ & NA & NA \\
\hline [50] & 2011 & Experimental and theoretical & 8.45 & 63.65 & NA & 10.26 \\
\hline [51] & 2011 & Experimental and theoretical & 9.4 & 41.9 & NA & 6.8 \\
\hline [52] & 2011 & Experimental & 9.8 & 40 & 51 & NA \\
\hline
\end{tabular}

Tables 1. The studies conducted of PVT water collectors

\section{CONCLUSION}

Based on the present review the following conclusions can be drawn:

From studies conducted of PVT water collector in 2011 to 2017, the energy and exergy efficiency of PVT water collector ranges from $28.5 \%$ to $85 \%$ and $6.8 \%$ to $14 \%$, respectively. From energy analysis, PV and thermal efficiency of PVT water collector ranges from $1.5 \%$ to $28 \%$ and $23 \%$ to $75 \%$, respectively.

The development of PVT water collectors is interesting and very promising area of research. Today, PVT water collectors using in solar water heater. 


\section{ACKNOWLEDGEMENTS}

The authors would like to thank the UKM for funding (GP-K020448) and (GGP-2017-045).

\section{REFERENCES}

[1] N.S. Nazri, et al., "Energy economic analysis of photovoltaic-thermal-thermoelectric (PVT-TE) air collectors. Renewable and Sustainable Energy Review, vol. 92, pp. 187-97, 2018.

[2] A. Fudholi, et al., "Review of solar drying systems with air-based solar collectors in Malaysia," Renewable and Sustainable Energy Review, vol. 51, pp. 1191-1204, 2015.

[3] N.S. Nazri, et al., "Mathematical modeling of photovoltaic thermal-thermoelectric (PVT-TE) air collector. International Journal of Power Electronics and Drive Systems (IJPEDS), vol. 9, no. 2, pp. 795-802, 2018.

[4] A. Fudholi, et al., "Review on exergy and energy analysis of solar air heater. International Journal of Power Electronics and Drive Systems (IJPEDS), vol. 9, no. 1, pp. 420-26, 2018.

[5] A. Fudholi, et al., "Review on solar collector for agricultural produce. International Journal of Power Electronics and Drive Systems (IJPEDS), vol. 9, no. 1, pp. 414-19, 2018.

[6] A. Fudholi, et al., "Primary study of tracking photovoltaic system for mobile station in Malaysia. International Journal of Power Electronics and Drive Systems (IJPEDS), vol. 9(1), pp. 427-32, 2018.

[7] M. Zohri, et al., "Exergy assessment of photovoltaic thermal with v-groove collector using theoretical study. TELKOMNIKA, vol. 16(2), pp. 550-57, 2018.

[8] M. Zohri, et al., "Photovoltaic thermal (PVT) system with and without fins collector: theoretical approach. International Journal of Power Electronics and Drive System (IJPEDS), vol. 8, no. 4, pp. 1756-63, 2017.

[9] A. Fudholi, et al., "R\&D of photovoltaic thermal (PVT) systems: an overview. International Journal of Power Electronics and Drive Systems (IJPEDS), vol. 9(2), pp. 803-10, 2018

[10] T. Bargene and O.M. Lovvik, "Model calculations on a fat plate solar heat collector with integrated solar cells," Solar Energy, vol. 55, no.6, pp. 453-462, 1995.

[11] B.J. Huang, et al., "Performance evaluation of solar photovoltaic/thermal systems,"Solar Energy, vol. 70, no. 5, pp. 443-448, 2001.

[12] H. Bahaidarah, et al., "Performane evaluation of a PV (photovoltaic) module by back surface water cooling for hot climatic conditions,"Energy, vol. 59, pp. 445-453, 2013.

[13] Shyam, et al., "Performance evaluation of N-photovoltaic thermal (PVT) water collectors partially covered by photovoltaic module connected in series: an experimental study," Solar Energy, vol. 134, pp. 134-302, 2016.

[14] M. Yahya, et al., "Energy and exergy analyses of solar-assisted fluidized bed drying integrated with biomass furnace,"Renewable Energy, vol. 105, pp. 22-29, 2017.

[15] S.A. Kalogirou, et al., "Exergy analysis on solar thermal systems: a better understanding of their sustainability,"Renewable Energy, vol. 85, pp. 1328-33, 2016.

[16] A. Fudholi, et al., "Energy and exergy analyses of photovoltaic thermal collector with $\nabla$-groove," Solar Energy, vol. 159, pp. 742-50, 2018.

[17] F. Sarhaddi, et al., "Exergetic performance assessment of a solar photovoltaic thermal (PV/T) air collector,"Energy and Buildings, vol. 42, pp. 2184-99, 2010.

[18] F. Sarhaddi, et al., "An improved thermal and electrical model for a solar photovoltaic thermal (PV/T) air collector," Applied Energy, vol. 87, pp. 2328-39, 2010.

[19] W. Mustafa, et al., "Numerical Investigation for Performance Study of Photovoltaic Thermal Nanofluid System. International Journal of Applied Engineering Research, 12(24), pp.14596-14602, 2017

[20] M.O. Lari and A.Z. Sahin, "Design, performance and economic analysis of a nanofluid-based photovoltaic/thermal system for residential applications," Energy Conversion and Management, vol. 149, pp. 467-84, 2017.

[21] C.N. Aisyah et al., "Kecekapan pengumpul PV/T menggunakan pengumpul terma reka bentuk pilin (Efficiency of PV/T collector using spiral thermal absorber design), Sains Malaysiana, vol. 47, no. 4, pp. 853-859, 2018[22] A. Fudholi, et al., "Performance analysis of photovoltaic thermal (PVT) water collectors,"Energy Conversion and Management, vol. 78, pp. 641-651, 2014.

[22] M. Rosen and I. Dincer, "Exergy as the confluence of energy, environment and sustainable development," Exergy, An International Journal, vol. 1, no.1, pp. 3-13, 2001.

[23] A. Fudholi, et al., "Energy and exergy analyses of solar drying system for red seaweed," Energy and Buildings, vol. 68, pp. 121-29, 2014.

[24] A. Fudholi, et al., "Performances and improvement potential of solar drying system for palm oil fronds,"Renewable Energy, vol. 78, pp. 561-65, 2015.

[25] [A. Fudholi, et al., "Performance analysis of solar drying system for red chili," Solar Energy, vol. 99, pp. 47-54, 2014.

[26] A. Fudholi, et al., "Energy analysis and improvement potential of finned double-pass solar collector," Energy Conversion and Management, vol. 75, pp. 234-40, 2013.

[27] A. Ibrahim, et al., "Efficiencies and improvement potential of building integrated photovoltaic thermal (BIPVT) system," Energy Conversion and Management, vol. 77, pp. 527-34, 2014.

[28] J. Yazdanpanahi, et al., "Experimental investigation of exergy efficiency of a solar photovoltaic (PVT) water collector based on exergy losses," Solar Energy, vol. 118, pp. 197-208, 2015

[29] H.A. Zondag, et al., "The yield of different combined PV-thermal collector designs," Solar Energy, vol. 74, pp. 253-269, 2003. 
[30] J. Modjinou, et al., "A numerical and experimental study of micro-channel heat pipe solar photovoltaics thermal system," Applied Energy, vol. 206, pp. 708-722, 2017.

[31] L. Hui, et al., " Building-integrated heat pipe photovoltaic/thermal system for use in Hong Kong," Solar Energy, vol. 155, pp. 1084-1091, 2017.

[32] Xu J. Ji, et al., "Numerical simulation and experimental validation of a high concentration photovoltaic/thermal module based on point-focus Fresnel lens," Applied Energy, vol. 168, pp. 269-281, 2016.

[33] R. Tripathi, et al., " Overall energy, exergy and carbon credit analysis of N partially covered Photovoltaic Thermal (PVT) concentrating collector connected in series," Solar Energy, vol. 136, pp. 260-267, 2016.

[34] D.B. Singh, et al., "Experimental studies of active solar still integrated with two hybrid PVT collectors,"Solar Energy, vol. 130, pp. 207-23, 2016.

[35] F. Yazdanifard, et al., "Investigating the performance of a water-based photovoltaic/thermal (PV/T) collector in laminar and turbulent flow regime,"Renewable Energy, vol. 99, pp. 295-306, 2016.

[36] K.K.. Tse, et al., "Performance evaluation and economic analysis of a full scale water-based photovoltaic/thermal (PV/T) system in an office building," Energy and Buildings, vol. 122, pp. 42-52, 2016.

[37] M. Rosa-Clot, et al., "Experimental photovoltaic-thermal Power Plants based on TESPI panel,"Solar Energy, vol. 133, pp. 305-314, 2016.

[38] M. Hu, et al., "Experimental study of the effect of inclination angle on the thermal performance of heat pipe photovoltaic/thermal (PV/T) systems with wickless heat pipe and wire meshed heat pipe," Applied Thermal Engineering, vol. 106, pp. 651-660, 2016.

[39] G.N. Tiwari, et al., "Exergoeconomic and enviroeconomic analyses of partially covered photovoltaic flat plate collector active solar distillation system,"Desalination, vol. 367, pp. 186-96, 2015.

[40] Shyam, et al., "Analytical expression of temperature dependent electrical efficiency of N-PVT water collectors connected in series,"Solar Energy, vol. 114, pp. 61-76, 2015.

[41] N. Palaskar and S.P. Deshmukh, "Performance analysis of especially flow design heat exchanger used in hybrid solar system," International Journal of Renewable Energy Research, vol. 5, 2015.

[42] S.N. Jahromi, et al., "Exergy and economic evaluation of a commercially available PV/T collector for different climates in Iran,"Energy Procedia, vol. 75, pp. 444-456, 2015.

[43] R.K. Mishra and G.N. Tiwari, "Energy and exergy analysis of hybrid photovoltaic thermal water collector for constant collection temperature mode,"Solar Energy, vol. 90, pp. 58-67, 2013.

[44] S. Dubey and A.A.O.Tay, "Testing of two different types of photovoltaic-thermal (PVT) modules with heat flow pattern under tropical climatic conditions," Energy for Sustainable Development, vol. 17, pp. 1-12, 2013.

[45] C. Cristofari, et al., "Innovative patented PV/TH Solar Collector: optimization and performance evaluation,"Energy Procedia, vol. 14, pp. 235-240, 2012.

[46] J.H. Kim and J.T. Kim, "The experimental performance of an unglazed PVT collector with two different absorber types," International Journal of Photoenergy, ID. 312168: 6, 2012.

[47] J.H. Kim and J.T. Kim., "The experimental performance of an unglazed PV-thermal collector with a fully wetted absorber,"Energy Procedia, vol. 30, pp. 144-151, 2012.

[48] P. Gang, et al., "Annual analysis of heat pipe PV/T systems for domestic hot water and electricity production," Energy Conversion and Management, vol. 56, pp. 8-21, 2012.

[49] S.Y. Wu, et al., "A heat pipe photovoltaic/thermal (PV/T) hybrid system and its performance evaluation," Energy and Buildings, vol. 43, pp. 3558-3567, 2011.

[50] P. Gang, et al., "A numerical and experimental study on a heat pipe PV/T system," Solar Energy, vol. 85, pp. 911921, 2011.

[51] W. He, et al., "Comparative experiment study on photovoltaic and thermal solar system under natural circulation of water," Applied Thermal Engineering, vol. 31, pp. 3369-3376, 2011.

\section{BIOGRAPHIES OF AUTHORS}

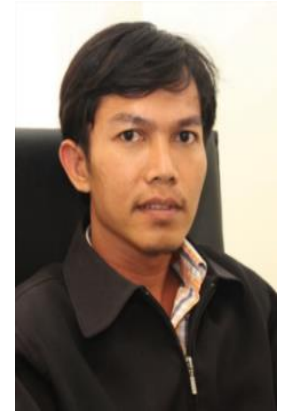

Ahmad Fudholi, Ph.D, M.Sc obtained his S.Si (2002) in physics. He was born in 1980 in Pekanbaru, Indonesia. He has working experience about 4 years (2004-2008) as Head of Physics Department at Rab University Pekanbaru, Riau, Indonesia. A. Fudholi started his master course in Energy Technology (2005-2007) at Universiti Kebangsaan Malaysia (UKM). His M.Sc thesis was on Wind/PV Hybrid System and the Ph.D thesis was about the Finned Double-Pass Solar Collectors for Drying of Seaweed. His M.Sc and Ph.D thesis under supervisor by Prof Dato' Dr. Kamaruzzaman Sopian. After his master he became Research Assistant at UKM up to 2012. After his Ph.D (2012) in renewable energy, he became Postdoctoral in Solar Energy Research Institute (SERI) UKM up to 2013. He joined the SERI as a Lecture in 2014. More than USD 310,000 research grant (15 grant/ project) in 2014-2017 was involved. More than $25 \mathrm{M}$.Sc project supervised and completed. Until now, he managed to supervise $5 \mathrm{Ph} . \mathrm{D}$ (4 main supervisors and 1 Co. supervisor), 3 Master's student by research mode, and 5 Master's student by coursework mode, he was also as examiner ( $3 \mathrm{Ph} . \mathrm{D}$ and $1 \mathrm{M} . \mathrm{Sc}$ ). His current research focuses on renewable energy, especially solar energy technology, micropower system, solar drying systems, and advanced solar thermal systems (solar assisted drying, solar heat pump, PVT systems). He has published more than 120 peer-reviewed papers, which 25 papers in ISI index 
(20 Q1, impact factor more than 3) and more than 60 papers in Scopus index, 16 more currently accepted manuscript, 20 more currently under review, and 2 book chapters. Addition, he has published more than 70 papers in international conferences. His total citations of 810 and hindex of 14 in Scopus (Author ID: 57195432490). His total citations of 1387 and h-index of 20 in google scholar. He is appointed as reviewer of high impact (Q1) journals He is appointed as reviewer of reputation journals. He is also appointed as editor journals. He has received several awards (Gold, Silver and Bronze) Medal He was also invited as speaker: Workshop of Scientific Journal Writing; Writing Scientific Papers Steps Towards Successful Publish in High Impact (Q1) Journals. He has 1 patent and 2 copyrights.
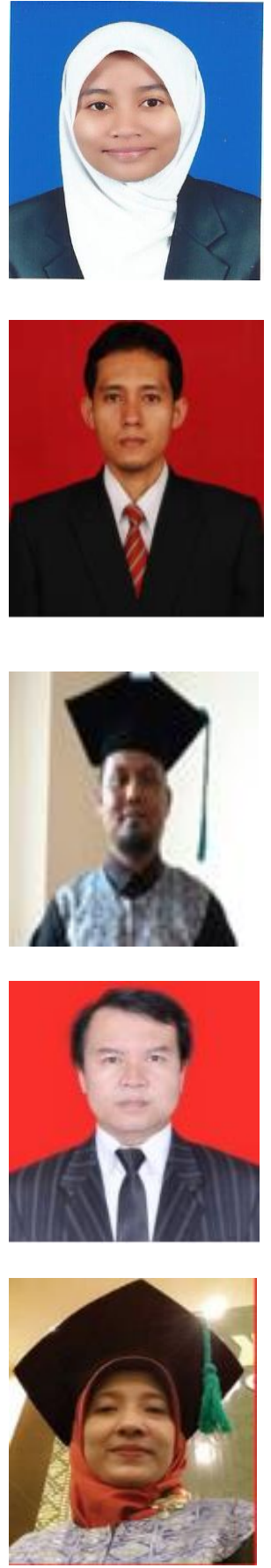

Nur Farhana Mohd Razali, M.Sc graduated with the M.Sc in Renewable Energy from Solar Energy Research Institute (SERI), Universiti Kebangsaan Malaysia (UKM), Malaysia. The M.Sc thesis was about the Exergy Analysis of Nanofluids Based Photovoltaic Thermal (PVT) Collector. Her M.Sc thesis under supervisor by Ahmad Fudholi Ph.D (main supervisor) and Prof Dr. Mohd Hafidz Ruslan (co. supervisor). She received "Excellent Thesis" Award from SERI UKM in 2017. More than 5 papers currently accepted manuscript in journals in Scopus index. She was appointed a Graduate Research Assistant (GRA) under Fundamental Research Grant Scheme (FRGS/1/2014/ST02/UKM/03/1) under project leader by Ahmad Fudholi Ph.D during his Master's degree.

Abrar Ridwan, S.Si, ST, MT is the head of centre of applied technology, head of mechanical engineering laboratory and a lecturer at Muhammadiyah University of Riau. His research interest includes combustion engineering, biomass gasification, energy conversion and solar energy. He was graduated from physic department of Brawijaya university and also in mechanical engineering at Muhammadiyah University of Malang (UMM). Since 8 years of his lecture was granted by Research and Technology Ministries of Indonesia (RistekDikti) for his research project. He is also involved in the UNDP-UNFCC program regarding municipal solid waste project in Riau Province and graduated his master of mechanical engineering from University of Indonesia. Currently he is focusing the research of how to optimize solar updraft power generator with any material as its heat storage.

Dr. Rado Yendra, M.Sc was born in Indonesia in 1977. He received Ph.D. degree in Statistical Science from The National University of Malaysia, Malaysia in 2014. He joined the Department of Mathematics from the State Islamic University of Sultan Syarif Kasim Riau, Indonesia and 2015 became a Vice-Dean from Faculty of Science and Technology. His main areas of research interest are statistical science and data mining.

Prof. Dr. Hartono, M.Pd from Pekanbaru, Indonesia. He is currently, a Professor at Faculty of Science and Technology, Universitas Islam Negeri Sultan Syarif Kasim (UIN Suska). He is Dean of Faculty of Science and Technology, UIN Suska Pekanbaru Riau, Indonesia. He was the Head, Department of Mathematics Education (2001-04); Deputy Dean, Faculty of Education (2004-13). His main contributions are in research methodology, statistical and as Training of Trainer. His major research efforts include designing E-learning, education method and education strategy. He has published more than 15 books in the field of education, statistic, analysis software, SPSS and general interests.

Ari Pani Desvina, S.Si, M.Sc from Indonesia. She graduated with the M.Sc in Statistical Science from The National University of Malaysia, Malaysia in 2010. She joined as lecturer at the Department of Mathematics, Faculty of Science and Technology, Universitas Islam Negeri Sultan Syarif Kasim (UIN Suska) in 2006. Carenntly, she is head of Mathematics Department of UIN Suska Riau, Indonesia. 

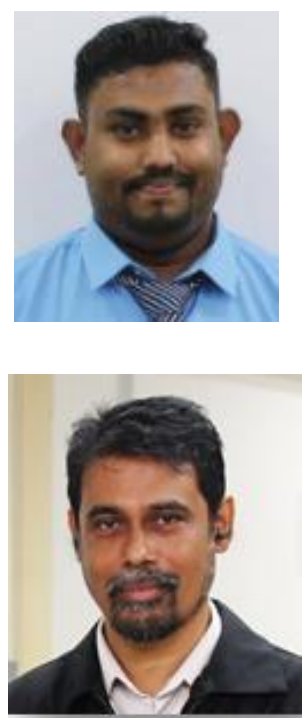

Dr Majid Khan joined the School of Mathematical Sciences, USM, as a lecturer (Operational Research) in May, 2017. He is a researcher and appointed fellow working in the field of seaweed cultivation, solar drying systems, processing, modelling and simulation. His research uses application of Iot, big data and simulation methods to improve model predictions of moisture losses during drying in control and uncontrolled environment. He is also interested in modelling the problems in engineering and other biological systems such as tissue culture and aquamarine. He uses the techniques from statistical theory, approach and existing application tools to develop mathematical model and finally to transform the model in industry application and to answer a range of inspired questions.

Prof Dato' Dr. Kamaruzzaman Sopian graduated with the BS Mechanical Engineering from the University of Wisconsin-Madison in 1985, the MS in Energy Resources University of Pittsburgh in 1989 and PhD in Mechanical Engineering from the Dorgan Solar Laboratory, University of Miami at Coral Gables in 1997. He has been involved in the field of renewable energy for more than 25-years.He has secure research funding from the Malaysian Minstry of Science and Malaysian Ministry of Education and industry for more than USD 6 million. He has conducted renewable enery courses the Asian School of Energy (2007-2014) funded by ISESCO, COMSAT, TIKA and UNESCO. He has published over 800 research papers in journals and conferences (SCOPUS h index $=53$, no. of citation $=9386)($ Google Scholar h index $=64$, no. of citation $=15531$ ). A total of $32 \mathrm{MSc}$ (coursework), $15 \mathrm{MSc}$ (research mode) and $50 \mathrm{PhD}$ candidates from various countries. He has undertaken short assignments in about 10 countries for international agencies and programs such as UNDP-GEF, UNIDO, ASEAN EU-Energy Facility, ASEAN-Australia Economic Co-operation Program, ASEAN-CIDA, JSPS-VCC, British Council CHICHE, ISESCO and UNESCO related to renewable energy technology. He has been appointed as the Honorary Professor of Renewable Energy, at University of Nottingham, United Kingdom (2009-2013). In addition, he has been appointed as the associate editors in high impact journals. He won several international awards for his academic contribution in renewable energy including the IDB (Islamic Development Bank) S\&T Prize 2013, World Renewable Energy Network Pioneer Award 2012, Malaysia Green Technology Award 2012, and the ASEAN Energy Awards (2005, 2007, 2013 and 2014). He has 4 patents, 20 patents pending, 6 copyrights, and 1 trademark for his innovation in renewable energy technology. The innovation and invention in renewable energy technology have won 80 medals in national and international innovation and invention competitions including special innovation awards such as Prix de L 'Environnement by the Swiss Society for Environmental Protection, 2001, Geneva, Sustainable Development Award INNOVA 2007, Special Prize, Korea Invention Promotion Association at the INPEX Pittsburgh 2008 and Energy and Environmental Award, at INNOVA 2013 in Brussels. His Royal Highness The Sultan of Perak conferred the Paduka Mahkota Perak and the Dato' Paduka Mahkota Perak in 2013. He was conferred as a Fellow of the Malaysia Academy of Sciences (FASc) in 2011. 